\title{
Analysis on the Positioning of Private Higher Education Institutions based on Fields of Science
}

\author{
M. Gunarto \\ Department of Management \\ Bina Darma University \\ Palembang, INDONESIA \\ mgunarto@binadarma.ac.id
}

\begin{abstract}
The growth of colleges in Indonesia increases every year, especially private Higher Education Institution (PTS). The higher the number of PTS is, the more intense the competition in getting prospective students is. The purposes of this study are: 1) to determine the position of each PTS among competitors' positions; 2 ) to determine the variability of the fields of science that are favored by students; 3) to determine the characteristics of each PTS based on the fields of science. This research was conducted by analyzing secondary data from PDDIKTI (Higher Education Data Base) reports. The analysis technique was bi-plot analysis. The results show that PTS in the form of an academy is in a specific position of a group of certain fields of science, but PTS in the form of a university is in a quite various position of a group of fields of science. Based on the observations on eight fields of science, the analysis result shows that the most demanded fields are health science and computer science. The least interested field is social study, whereas the interest of students to the fields of Jurisprudence, Agriculture science, Economics, Engineering, and Education is relatively balanced. The characteristics of each PTS are shown by the closeness to the fields of science. The results could be used by the PTS for collecting information on market segment and as consideration for determining an effective marketing strategy in gaining prospective students.
\end{abstract}

Keywords—private colleges, positioning, biplot analysis

\section{INTRODUCTION}

Choosing a higher education institution is different from choosing a product; it involves considerations on values in the future. Yet, there are some similarities in choosing such institutions, particularly for the private ones. Prospective students will determine several preferences before selecting the college based on their interests. There are several factors in determining students' preferences for choosing a higher education institution; one of which is the institution's reputation, which is reflected by its brand equity. An established brand reflects the credibility of the product. It also helps a company to expand its market in dealing with intense competition. Brand equity is also a prominent aspect for a company in improving its competitiveness and marketing strategy [1].

The market competition in providing educational service among private higher education institution (PTS) is relatively stiff as their performances are based on their finance, which is from their students [2]. Currently there are 4.219 colleges and universities in Indonesia which consist of 121 public universities and colleges and 3.098 PTSs, with 22.847 majors and departments [3]. All PTSs face the impact of the competition in gaining students to study at their institutions. It can be seen from the report that $30-40 \%$ of private colleges and universities are about to bankrupt. This condition is also faced by PTSs in Palembang, particularly for bachelor and diploma degree. In fact, none of the institutions conduct student admission test because the number of applicants is less than the student quota.

Until now, there have been assessments on college performance, for instance those from Badan Akreditasi Nasional Perguruan Tinggi/National Agency of Higher Education Institutions Accreditation (BAN-PT) and Lembaga Akreditasi Mandiri/Independent Accreditation Institution (LAM-PT), not to mention those from other institutions in Asian and international level. Yet, they are not the only basis for the society in choosing colleges to study. It can be seen in the fact that many students choose majors or colleges with accreditation rate $C$ [4]. This particular condition shows that there are several other factors contributing to the selection of the colleges; one of which is the interest on a field of study. This study is aimed at identifying which higher education institutions and fields of study that invite prospective students better. Hence, colleges and universities could specify their target markets and select appropriate marketing strategies in gaining students to study in the institutions [5].

The position in the market has been long known as an important factor in dealing with the pressures of competition. A company that has particular position in particular market relatively has more advantages. The positioning of company in the framework of general segmentation-targeting-positioning plays an important role in marketing strategy. The positioning strategy could improve the performance of the company [6].

The effective position in a market is a process of having mutual benefit between producer and consumer. It is based on the understanding of consumers' unique needs. Effective positioning offers consumers benefits that meet the needs [1]. To be able to apply appropriate marketing strategy, it is necessary to know the position of a product among its competitors in order to be able to determine the product's market segment. The position in the market reflects how consumers perceive the product's attributes or performance compared to those of its competitors. Positioning is about managing offers to market in order to set a specific, different and desired place in the minds of target consumers compared to the competitors' [7]. It is shown that the position of schools 
is unique as it shapes the school images-in that one is better than the others [8]. In facing competition among private colleges and universities, new strategies should be employed [9]. In this case, the strategy is positioning in which a college or university attempts to make a unique differentiation within consumers' mind to create an image that it is better than its competitors.

As well as in products, private universities and colleges need to have an effective marketing strategy in increasing the number of their students through market segmentation, targeting and positioning. Focused on higher education institutions in Palembang, this study is aimed at identifying 1) the position of each college, 2) the fields of science that are favored by students, and 3) the characteristics of each private college and university based on particular fields of science.

\section{Methodology}

The data used in this study is secondary data from PDPT report in odd semester 2014, which was gathered from Kopertis Wilayah II. The population of the study is all private higher education institutions in Palembang: 68 institutions and 267 programs. The samples selected in the study were based on biplot analysis: 29 institutions were selected through purposive sampling with the criteria that the institutions have more than 300 students. The institutions were UMP, UNPAL, UIGM, UNISTI, UIBA, UPGRI, UBD, UTAMSIS, UNANTI, UKB, STMIK GIMDP, STT MUSI, STIE MUSI, STIE APRIN, STIK BINHUS, STIK SKHD, STIE MDP, STISIPOL, STIAPADS, STIKESMAS WD, STIM AMKOP, AKBID BM, AKPER KESDAM, AKBID PONDOK, AKBID AISIYAH, AMIK Sigma, AMIK BINAS, and STMIK PALC.

The observed variables were the 29 institutions and the observed attributes were eight fields of science: 1) Economics, 2) Jurisprudence, 3) Education, 4) Health Science, 5) Computer Science, 6) Agriculture Science, 7) Social study, and 8) Technical Engineering. The data was analyzed by SPSS for Windows software [4].

The biplot analysis is shown in charts with the following interpretations:

1. The location of the institutions. The closer the institution with another is, the more similar they are.

2. The length of the vectors. The longer the vector of the attributes is, the more various the data is, and vice versa.

3. The angles of two attribute vectors. The angles show the correlation of the attributes. The lower the angles (almost $0^{\circ}$ ) are, the more positive the correlation is. In contrast, the higher they are, the more negative the correlation is. The attribute vector angles that are $90^{\circ}$ show that the attributes do not correlate.

4. The closeness between the private higher education institutions and their attributes. A group of private colleges or universities that are close and in line with their attributes shows that the group has high attribute score. The further it is, the higher its attribute score is. It is vice versa if the group is in the opposite direction with its attribute vector.

\section{RESUlt AND ANALYSIS}

\section{A. Descriptive Analysis}

The number of private higher education institutions that are supervised by Kemenristekdikti (The Higher Education Directorate of Ministry of Research and Technology) is 68, ranging from academy, polytechnic, college and university. The detailed data is shown in Table 1.

TABLE I. DATA PTS AND SUM OF STUDENT IN PALEMBANG CITY

\begin{tabular}{|c|l|c|c|c|c|}
\hline Number & $\begin{array}{c}\text { Types of } \\
\text { PTS }\end{array}$ & $\begin{array}{c}\text { Sum } \\
\text { of } \\
\text { PTS }\end{array}$ & $\begin{array}{c}\text { Sum of } \\
\text { Study } \\
\text { Programs }\end{array}$ & $\begin{array}{c}\text { Sum of } \\
\text { Students }\end{array}$ & $\begin{array}{c}\text { Sum of } \\
\text { Lecturers }\end{array}$ \\
\hline 1 & Academy & 26 & 31 & 5.990 & 210 \\
\hline 2 & Polytechnic & 4 & 13 & 1.002 & 54 \\
\hline 3 & College & 28 & 73 & 24.160 & 524 \\
\hline 4 & University & 10 & 150 & 47.576 & 1.304 \\
\hline & Sum & $\mathbf{6 8}$ & $\mathbf{2 6 7}$ & $\mathbf{7 8 . 7 2 8}$ & $\mathbf{2 . 0 9 2}$ \\
\hline
\end{tabular}

Source: PDPT Data, 2015

From table 1, it can be seen that most students are registered at universities due to their variety of majors. The average number of active students is 1.175 per institutions and 295 per each major with the average of lecturer for each major is 8 lecturers. The lecturer-student ratio for each major is $1: 31$. The ratio shows that most majors do not meet the standard ratio of good higher education institution, which was set at $1: 25$ by The Higher Education Directorate [10].

\section{B. Biplot Analysis}

There are five types of PTS: polytechnic, academy, college, institute and university. Each institution has different characteristics from each other. From their fields of science, academy and college have homogenous subjects while polytechnic, institute and university have more varied subjects. There are eight fields of science which were observed in this study: 1) economics, 2) jurisprudence, 3) education, 4) health science, 5) computer science, 6) agriculture, 7) social science and 8) engineering. The result of biplot analysis of the 29 private higher education institutions in Palembang, which were selected as samples, is shown in Figure 1.

Figure 1 shows that the distribution of the institutions and the eight fields of science. The bi-plot analysis in Figure 1 shows that the data diversity is $53,41 \%$ with two dimensions, which should be explained in 8 dimensions, to show the positioning of each institution.

Based on the closeness among institutions, it is found that 29 institutions can be classified into 10 groups based on their similar conditions:
a) Group 1 : UIGM and UNPAL;
b) Group 2 : UMP;
c) Group 3 : UNISTI;
d) Group 4 : STIK BINHUS, AKBID BM, AKPER
Kesdam, STIK SKHD, AKBID
COTTAGE, AKBID Aisiyah, UKB, 
STIKESMAS WD, STISIPOL and STIAPADS;

e) Group 5 : STIE MDP and STIM AMKOP;

f) Group $6:$ STT MUSI and AMIK Sigma;

g) Group 7: STMIK GIMDP, AMIK BINAS and STMIK PALC;

h) Group 8 : UBD;

i) Group 9 : UPGRI;

j) Group 10 : UIBA, STIE MUSI, STIE Aprin, UTAMSIS and UNANTI.

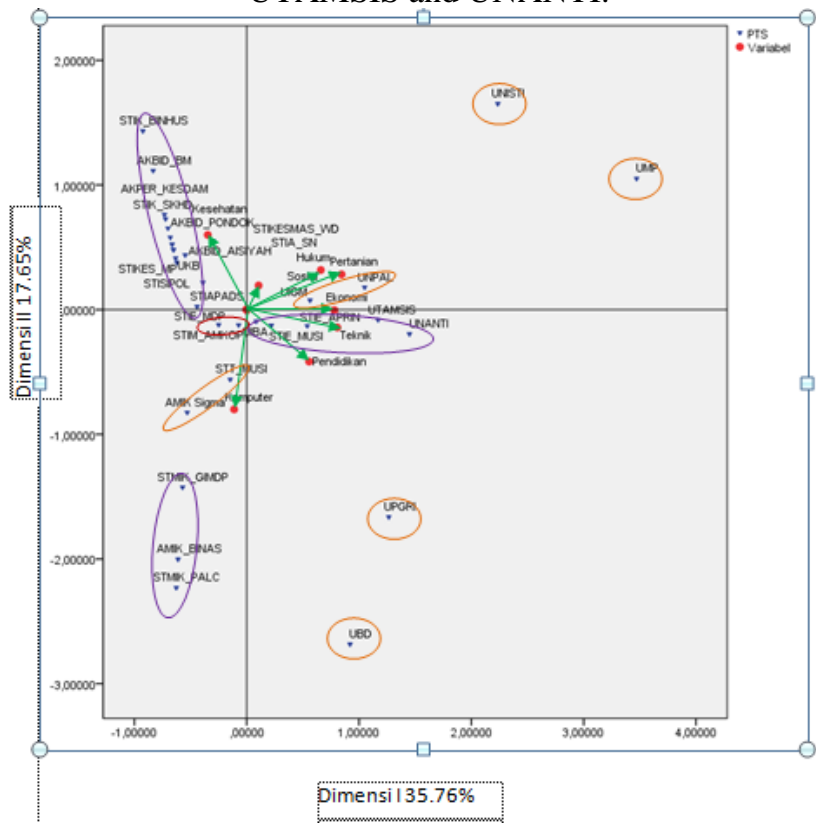

Figure 1. Private higher education institutions' subjects mapping

Figure 1 shows that the distribution of the institutions and the eight fields of science. The bi-plot analysis in Figure 1 shows that the data diversity is $53,41 \%$ with two dimensions, which should be explained in 8 dimensions, to show the positioning of each institution.

Based on the closeness among institutions, it is found that 29 institutions can be classified into 10 groups based on their similar conditions:

a) Group 1 : UIGM and UNPAL;

b) Group 2 : UMP;

c) Group 3 : UNISTI;

d) Group 4 : STIK BINHUS, AKBID BM, AKPER

Kesdam, STIK SKHD, AKBID

COTTAGE, AKBID Aisiyah, UKB, STIKESMAS WD, STISIPOL and STIAPADS;

e) Group 5 : STIE MDP and STIM AMKOP;

f) Group $6:$ STT MUSI and AMIK Sigma;

g) Group 7: STMIK GIMDP, AMIK BINAS and STMIK PALC;

h) Group $8:$ UBD;

i) Group 9 : UPGRI;

j) Group 10 : UIBA, STIE MUSI, STIE Aprin, UTAMSIS and UNANTI.

In Group 1, UIGM and UNPAL are similar in that both of them compete to attract students to study at them. Both of them also have similar subjects. UMP in Group 2 is the only private higher education institution that has medical science subject, which makes it a solitary group.
UNISTI in Group 3 is a university which is prominent with its jurisprudence study. In group 4, there are ten institutions which mostly emphasize on health science, with exception for STISIPOL and STIAPADS which focus on social study. STT MUSI and AMIK Sigma are in group six for their similarities in their subjects. The institutions in group 7 are similar in that they all focus on computer science. The only institution in group 8, UBD, has different characteristics which make it different from other institutions. Similarly, group 9 only has one institution, UPGRI, for its particular characteristic: it focuses on education. Group 10 consists of institutions whose concerns are on economics and engineering.

The length of the vectors of each field of study shows the data variation of the field. The vectors of the eight fields of science are shown by arrows from the center point to the observed fields. The longer the vector is, the more the students registered in the field. The longest vectors are those of health science and computer science, which means that the number of students of those subjects is higher than that of any other subjects. The number of students studying jurisprudence, agriculture, economics, engineering and education is relatively medium. The shortest vector is that of social study. From the correlation of the vectors, it can be concluded that social study, jurisprudence, agriculture and economics have relatively similar variations. Similar finding is also found in engineering and education. On the other hand, health science and computer science create their own group. This mapping shows value proposition that focuses on customers [3].

From the closeness of the groups of higher education institutions and the observed fields of science, the correlation between the institutions and the fields of science can be analyzed. The institutions that are close to particular vector direction reflect that they are closely associated to those fields of science. From Figure 1, the institutions can be categorized into four groups:

a) Group 1, which consists of STIA SN, UNISTI, UIGM, UNPAL and UMP is close to social study, jurisprudence, agriculture, and economics.

b) Group 2, consisting of UIBA, STIE MUSI, STIE APRIN, UTAMSIS, UNANTI, UPGRI and UBD, is close to engineering and education. The institution emphasizing on education with highest number of students is UPGRI. Similarly, UBD is the institution focusing on education and computer science with most number of students.

c) Group 3, with STIE MDP, STIM AMKOP, STT MUSI, AMIK Sigma, STMIK GIMDP, AMIK BINAS and STMIK PALC as its group members, is the group of institutions concerning on computer science. STMIK PALC is the institution of this group with the highest number of students.

d) Group 4 which consists of STIK BINHUS, AKBID BM, AKPER KESDAM, STIK SKHD, AKBID PONDOK, AKBID AISIYAH, STIKES, UKB, STIKESMAS WD, STISIPOL dan STIAPADS, is the group of institutions that emphasize on health science, with an exception 
for STISIPOL and STIAPADS as they focus on social study.

\section{CONCLUSION}

The results of the analysis show that institutions such as academies and colleges focus on particular fields of study but universities have more various subjects. Health and computer science are the most attractive subjects in students' perspective while social study is the least attractive subject. Other subjects, such as jurisprudence, agriculture, economics, engineering and education, are the relatively balanced in terms of students' preference. The characteristics of the institutions are determined by the association between the institutions and particular fields of science. This study can be used by private higher education institutions as information to know the market segment and as consideration to determine effective marketing strategy to be used in gaining prospective students.

\section{ACKNOWLEDGMENT}

Funds: Directorate General of Higher Education in 2014, research Beginners Lecturer with contract No. 033 / SPK / LPPM / Univ-BD / VI / 2014 dated June 23, 2014.

\section{REFERENCES}

[1] P. S. Manhas, "Strategic Brand Positioning Analysis through Comparison of Cognitive and Conative Perceptions," J. Econ. Financ. Adm. Sci., vol. 15, no. 29, pp. 15-34, 2010.

[2] R. E. Wright, "Student Focused Marketing: Impact of Marketing Higher Education Based on Student Data and Input," pp. 88-94, 2013.

[3] Direktorat Jenderal Pendidikan Tinggi, "SRV2 PDDIKTI : Pangkalan Data Pendidikan Tinggi," www.forlap.dikti.go.id, Jakarta, 2015.

[4] M. Gunarto and M. A. Syarif, "Penggunaan Analisis Biplot pada Pemetaan Perguruan Tinggi Swasta di Kota Palembang," Forum Manaj. Indones. 6, pp. 1-13, 2014.

[5] H. J. Gershon, "Strategic positioning: Where does your organization stand?," J. Healthc. Manag., vol. 48, no. 1, pp. $12-$ $14,2003$.

[6] S. O. Mokaya, "Market Positioning and Organizational Performance in the Airlines Industry in Kenya," vol. 1, no. 4, pp. 121-132, 2012.

[7] P. Kotler and G. Armstrong, Principles of Marketing, Fifteenth. England: Pearson Education Limited, 2014.

[8] Melissa, "Pendekatan analisis biplot dalam mendeskripsikan posisi relatif antar SMA di kota Denpasar," e-Jurnal Mat., vol. 1, no. 1, pp. 47-51, 2012.

[9] N. S. Dugis, T. Intan, and P. Hartiana, "Meaningful Marketing Communation Strategy in Higher-Education: Sebagai Usaha Peningkatan Brand Perguruan Tinggi Swasta Studi Kasus HigherEducation Branding di Universitas Katolik Widya Mandala Surabaya," vol. 2, no. 2, 2012.

[10] Departemen Pendidikan Nasional Direktorat Jenderal Pendidikan Tinggi, Penetapan Daya Tampung Mahasiswa. Indonesia, 2007. 